\title{
Karakter Rhizobakteri Pelarut Fosfat Potensial dari Rhizosfer Tumbuhan Mangrove Teluk Awur Kabupaten Jepara secara Mikrobiologi
}

\author{
Eka Oktaviani ${ }^{1}$, Arina Tri Lunggani², dan Rejeki Siti Ferniah ${ }^{2}$ \\ ${ }^{1}$ Jurusan Agroteknologi, Fakultas Pertanian, Universitas Jenderal Soedirman; e-mail: oktaviani@unsoed.ac.id \\ 2 Departemen Biologi Fakultas Sains dan Matematika Universitas Diponegoro
}

\begin{abstract}
ABSTRAK
Ekosistem mangrove Teluk Awur yang terletak di Kabupaten Jepara, Provinsi Jawa Tengah, merupakan salah satu ekosistem mangrove yang mengalami kerusakan cukup parah karena perluasan lahan budidaya ikan (tambak), sehingga mendorong terjadinya erosi pantai. Peremajaan kembali dan konservasi ekosistem mangrove dapat dilakukan dengan menggunakan bakteri tanah yang mampu mendukung pertumbuhan tanaman atau yang biasa disebut Plant Growth Promoting Rhizobacteria (PGPR). Salah satu mekanisme pendukung pertumbuhan tanaman oleh kelompok PGPR adalah dengan aktivitas pelarutan fosfat karena fosfat dalam tanah berada dalam bentuk yang sulit diserap oleh tanaman. Penelitian ini bertujuan untuk memperoleh isolat Rhizobakteri pelarut fosfat yang unggul dalam melarutkan fosfat secara in-vitro dan mengetahui karakter isolat yang diperoleh. Isolasi dan penapisan rhizobakteri pelarut fosfat dilakukan menggunakan medium Pikovskaya agar. Karakterisasi isolat potensial dilakukan secara mikrobiologi dan atau uji aktivitas biokimia. Hasil penelitian menunjukkan bahwa rhizobakteri pelarut fosfat potensial yang berhasil diisolasi, secara mikrobiologi teridentifikasi ke dalam genus Enterobacter.
\end{abstract}

Kata kunci: Karakterisasi, Rhizobakteri, Fosfat, Teluk Awur, Enterobacter

\begin{abstract}
Mangrove ecosystem of Teluk Awur, which is located in Jepara Regency, is one of the mangrove ecosystems that suffered severe damage due to the expansion of fish farming land (ponds). Rejuvenation and conservation of mangrove ecosystems can be done by using bacteria that support mangrove plant growth, which commonly called Plant Growth Promoting Rhizobacteria (PGPR). One of the supporting mechanisms of plant growth by the PGPR group can be carried out with phosphate dissolving activity because phosphate in the soil is in a form that is difficult to absorb by plants. This study aims to obtain potential phosphate solubilizer Rhizobacteria in dissolving phosphate in-vitro and to determine character of the obtained isolate. Isolation and screening of potential phosphate solubilizer Rhizobacteria were carried out using Pikovskaya agar medium. Microbiological characterization of potential isolate was carried out based on microbiological and/or biochemical activity. The results showed that potential phosphate solubilizer Rhizobacteria, microbiologically identified as Enterobacter.
\end{abstract}

Keywords: Characterization, Rhizobacterium, Phosphate, Teluk Awur, Enterobacter

Citation: Oktaviani, E., Lunggani, A.T., dan Ferniah, R.S. (2020). Karakterisasi Rhizobakteri Pelarut Fosfat Potensial dari Rhizosfer Tumbuhan Mangrove Teluk Awur Kabupaten Jepara secara Mikrobiologi. Jurnal Ilmu Lingkungan, 18(1), 58-66, doi:10.14710/jil.18.1.58-66

\section{Latar Belakang}

Hariyono (2007) menuliskan bahwa salah satu ekosistem mangrove di pesisir utara Pulau Jawa yang mengalami kerusakan ekosistem cukup parah adalah ekosistem mangrove Teluk Awur yang terletak di Kabupaten Jepara Jawa Tengah. Kerusakan ekosistem daerah ini terjadi karena perluasan lahan budidaya ikan (tambak) di kawasan Kabupaten Jepara sehingga mendorong terjadinya erosi pantai. Peremajaan kembali dan konservasi ekosistem mangrove merupakan suatu hal penting yang dapat dilakukan di daerah tersebut dengan penanaman kembali dan pemeliharaan komponen penyusun hutan mangrove.
Salah satu metode yang dapat mendukung cara tersebut adalah dengan menggunakan Plant Growth Promoting Rhizobacteria (PGPR) untuk meningkatkan perkembangan mangrove baik secara alami maupun buatan (Sahoo \& Dahl, 2009).

Kelompok PGPR merupakan kelompok bakteri tanah yang mampu meningkatkan pertumbuhan dan perkembangan tanaman melalui beberapa mekanisme pendukung (Thuller et al., 2003; Lee et al., 2005; Dewi, 2007; Bariusso et al., 2008; Sahoo \& Dahl, 2009; Dastager et al., 2009; Ahemad \& Khan, 2010). Mekanisme pendukung pertumbuhan tanaman dapat berupa peningkatan ketersediaan nutrisi (melalui 
penambatan nitrogen secara biologis), produksi substansi pengatur pertumbuhan (auksin, sitokinin, giberelin, dan etilen), peningkatan kemampuan hidup tanaman (melalui aktivitas kompetisi untuk mendapatkan nutrisi yang dibutuhkan tanaman), peningkatan penyerapan nutrien tanaman (melalui aktivitas pelarutan fosfat), perbaikan struktur tanah dan perlindungan tanaman terhadap patogen dan mikroorganisme penyebab penyakit yang merugikan tanaman (melalui aktivitas pengendalian secara biologi terhadap patogen tertentu) (Dastager et al., 2009; Ahemad \& Khan, 2010; Girish et al., 2010). Mekanisme pendukung pertumbuhan tanaman dengan peningkatan penyerapan nutrisi yang dibutuhkan dapat dilakukan melalui aktivitas pelarutan fosfat, karena fosfat dalam tanah berada dalam bentuk senyawa yang sulit diserap oleh tanaman (Mehta \& Nautiyal, 2001; Sahoo \& Dahl, 2009; Girish et al., 2010).

Penelitian tentang penerapan PGPR untuk peremajaan kembali dan konservasi ekosistem mangrove di Indonesia masih sangat sedikit, sementara ekosistem mangrove memiliki fungsi penting yang berhubungan dengan perlindungan daerah pesisir pantai. Pengetahuan tentang asosiasi Rhizobakteri dengan ekosistem mangrove belum banyak diketahui (Bharathkumar et al., 2008; Sahoo \& Dahl., 2009). Pengetahuan tentang mikroorganisme yang terdapat di lingkungan dengan kondisi salinitas tertentu masih terbatas apabila dibandingkan dengan mikroorganisme darat (Mishra et al., 2009). Penelitian ini bertujuan untuk mendapatkan isolat rhizobakteri pelarut fosfat potensial dari rhizosfer tumbuhan mangrove Teluk Awur Kabupaten Jepara dan mengetahui karakter isolat tersebut secara mikrobiologi dan atau aktivitas biokimiawi. Penelitian tentang mikroorganisme menguntungkan dari kelompok PGPR tersebut menjadi hal yang penting dilakukan dalam pencapaian tujuan pemeliharaan dan konservasi ekosistem mangrove di kawasan mangrove Teluk Awur, Kabupaten Jepara, Provinsi Jawa Tengah.

\section{Metode Penelitian}

Pengambilan sampel tanah rhizosfer mangrove dilakukan di ekosistem mangrove Teluk Awur Kabupaten Jepara. Proses isolasi, penapisan isolat potensial dan karakterisasi secara mikrobiologi dan atau aktivitas biokimia dilakukan di Laboratorium Mikrobiologi Jurusan Biologi Fakultas Sains dan Matematika Universitas Diponegoro. Analisis kandungan fosfat total dalam sampel tanah dilakukan di Laboratorium Kimia Analitik Jurusan Kimia Fakultas Sains dan Matematika Universitas Diponegoro.

\subsection{Pengambilan sampel tanah rhizosfer tumbuhan mangrove}

Tanah rhizosfer dikumpulkan dengan metode Purpossive Sampling (Fachrul, 2007) berdasarkan jenis tumbuhan yang berbeda, yaitu Sonneratia sp., Rhizophora sp. dan Calotropis gigantea. Tanah rhizosfer diambil di sekitar perakaran pada jarak 1-2 mm pada empat titik pengambilan sampel untuk masing-masing rhizosfer tumbuhan mangrove. Sebanyak kurang lebih $1 / 4 \mathrm{~kg}$ sampel tanah dari masing-masing pengambilan satu tumbuhan mangrove tersebut disimpan dalam plastik hitam dalam kondisi segar untuk dibawa ke laboratorium.

\subsection{Analisis kandungan fosfat total dalam sampel tanah}

Sampel tanah dari ketiga rhizosfer tumbuhan mangrove dikirimkan ke laboratorium Kimia Analitik Jurusan Kimia FSM UNDIP sebanyak $10 \mathrm{~g}$ untuk dilakukan analisis terhadap kandungan fosfat total. Analisis dilakukan dengan menggunakan metode Pengasaman Stannous Chloride untuk semua jenis sampel tanah.

\subsection{Isolasi Rhizobakteri pelarut fosfat dari sampel tanah}

Teknik isolasi dilakukan menurut metode dari Waluyo (2008) dengan modifikasi. Sebanyak $10 \mathrm{~g}$ tanah segar diencerkan ke dalam $90 \mathrm{ml}$ akuades steril. Suspensi yang terbentuk dihomogenkan, kemudian sebanyak $1 \mathrm{ml}$ aliquot dipindahkan dengan mikropipet steril ke dalam tabung reaksi steril yang telah berisi $9 \mathrm{ml}$ akuades steril. Suspensi dihomogenkan selama 10 detik dan dilakukan pengenceran bertingkat dari $10^{-1}$ hingga $10^{-5}$. Suspensi tanah masing-masing $0,1 \mathrm{ml}$ ditaburkan ke dalam cawan petri yang kemudian diisi dengan medium Pikovskaya (PVK) agar (Banerjee et al., 2010). Kultur diinkubasi selama 6 hari pada suhu $25^{\circ} \mathrm{C}$. Zona bening yang mengelilingi koloni menunjukkan aktivitas pelarutan fosfat anorganik dalam medium tersebut. Semua koloni yang mengahasilkan zona bening diambil untuk dimurnikan pada medium yang baru (Bharathkumar et al., 2008).

\subsection{Penampisan isolat unggul Rhizobakteri pelarut fosfat lokal}

Semua isolat diperkaya dalam medium Nutrient Broth (NB). Kultur kemudian diinkubasi dalam pengocok orbital dengan kecepatan 120 rpm pada suhu kamar. Analisis kuantitatif fosfat terlarut dilakukan dengan menginokulasikan sel dengan kepadatan sebanyak $\pm 10^{8} \mathrm{cfu} / \mathrm{ml}$ untuk masingmasing kultur bakteri. Pertumbuhan bakteri diamati setelah inokulasi hari ke-7. Daerah bening yang mengelilingi koloni pertumbuhan bakteri kemudian diukur untuk diketahui efisiensi pelarutan fosfat masing-masing bakteri yang diuji. Efisiensi pelarutan 
fosfat dihitung berdasarkan rumus dari Girish et al. (2010), yang membandingkan diameter pelarutan fosfat dalam medium dengan diameter koloni yang terbentuk.

$$
\mathrm{EP}=\frac{\text { Diameter Pelarutan }}{\text { Diameter Koloni }}
$$

\subsection{Karakterisasi isolat Rhizobakteri pelarut fosfat potensial}

Karakterisasi Morfologi Koloni Rhizobakteri (Cappuccino \& Sherman, 1987)

Koloni isolat Rhizobakteri potensial diamati warna, tepian, bentuk dan elevasi koloni dalam medium Nutrient Agar (NA). Karakter koloni dalam medium cair juga diamati dalam medium NB.

\section{Karakterisasi Morfologi Sel Rhizobakteri}

Morfologi sel diamati dengan pewarnaan gram (Cappucino \& Sherman, 1987). Satu ose isolat Rhizobakteri kemudian disuspensikan ke dalam akuades steril dan difiksasi di atas kaca benda bersih. Olesan Rhizobakteri diberi 2-3 tetes pewarna kristal violet (gram A) dan dibiarkan selama 1 menit. Zat warna berlebih dicuci dengan air mengalir dan dikeringanginkan. Olesan Rhizobakteri digenangi dengan 2 tetes larutan lugol's iodin (gram B), dibiarkan selama 1 menit. Zat warna berlebih dicuci dengan air mengalir dan dikeringanginkan. Olesan dicuci dengan larutan alkohol aseton (gram C) selama 30 detik. Zat pewarna berlebih dibilas dengan air mengalir dan dikeringanginkan. Olesan diberi cat safranin (gram D) selama 2 menit, dicuci dengan air mengalir dan dikeringanginkan. Preparat diamati di bawah mikroskop dengan perbesaran kuat (1000x) menggunakan minyak emersi. Bakteri gram negatif akan berwarna merah, sedangkan gram positif akan berwarna ungu.

\section{Karakterisasi Aktivitas Biokimia Rhizobakteri}

Uji Hidrolisis Pati

Uji ini dilakukan berdasarkan metode Cappuccino \& Sherman (1987). Uji hidrolisis pati positif terdapat daerah bening pada medium yang mengandung pati setelah penambahan larutan lugol.

\section{Uji Fermentasi Karbohidrat}

Uji ini dilakukan berdasarkan metode Cappuccino \& Sherman (1987). Uji fermentasi karbohidrat positif jika warna merah medium fermentasi berubah menjadi kuning (bakteri melakukan fermentasi gula dan menghasilkan asam). Gelembung yang terdapat dalam tabung durham menunjukkan bahwa fermentasi tersebut juga menghasilkan gas karbondioksida $\left(\mathrm{CO}_{2}\right)$.

\section{Uji Penggunaan Sitrat}

Uji ini dilakukan berdasarkan metode Cappuccino \& Sherman (1987). Satu ose isolat Rhizobakteri ditanam pada medium Simmon Sitrat
Agar miring. Kultur diinkubasi selama 24 hingga 48 jam. Perubahan yang terjadi diamati dan dicatat. Uji positif penggunaan sitrat ditunjukkan jika terjadi perubahan warna medium hijau menjadi biru.

\section{Uji Produksi Indol}

Uji ini dilakukan berdasarkan metode Cappuccino \& Sherman (1987). Uji indol positif jika terbentuk cincin merah di permukaan medium dengan penambahan tiga tetes pereaksi Kovac's.

\section{Uji Aktivitas Enzim Katalase}

Uji ini dilakukan berdasarkan metode Cappuccino \& Sherman (1987). Uji ini positif jika terdapat gelembung gas oksigen $\left(\mathrm{O}_{2}\right)$ pada biakan yang diuji dengan larutan $\mathrm{H}_{2} \mathrm{O}_{2} 3 \%$.

\section{Karakter Pertumbuhan Isolat dengan Variasi Faktor} Lingkungan (Cappuccino \& Sherman, 1987)

Suhu

Satu ose isolat Rhizobakteri dari medium NA miring kemudian diinokulasikan dengan ose bulat ke dalam medium NB steril dengan tiga kali ulangan. Suspensi kemudian diinkubasikan ke dalam tiga variasi suhu, yaitu $25^{\circ} \mathrm{C}, 37^{\circ} \mathrm{C}$ dan $47^{\circ} \mathrm{C}$ selama kurang lebih 24 jam. Satu tabung medium NB steril tanpa inokulasi bakteri juga diinkubasikan ke dalam inkubator dengan berbagai variasi suhu tersebut sebagai kontrol perlakuan. Hasil pengamatan kualitatif pertumbuhan dalam variasi suhu kemudian diamati dengan kontrol sebagai pembanding.

\section{Salinitas (Kadar Garam)}

Satu ose isolat Rhizobakteri dari medium NA miring kemudian diinokulasikan dengan ose bulat ke dalam medium NB steril yang telah dimodifikasi oleh beberapa konsentrasi salinitas dengan tiga kali ulangan. Salinitas medium NB diatur sebesar 0,85\% $(\mathrm{w} / \mathrm{v}), 5 \%(\mathrm{w} / \mathrm{v}), 10 \%(\mathrm{w} / \mathrm{v})$ dan $15 \%(\mathrm{w} / \mathrm{v})$. Suspensi kemudian diinkubasikan dalam suhu kamar selama kurang lebih 24 jam. Satu tabung medium NB steril tanpa inokulasi bakteri juga diinkubasikan ke dalam inkubator dengan berbagai variasi salinitas tersebut sebagai kontrol perlakuan. Hasil pengamatan kualitatif pertumbuhan dalam variasi salinitas kemudian diamati dengan kontrol sebagai pembanding.

\section{Derajat Keasaman (pH)}

Satu ose isolat Rhizobakteri dari medium NA miring kemudian diinokulasikan dengan ose bulat ke dalam medium NB steril yang telah dimodifikasi oleh beberapa tingkatan $\mathrm{pH}$ dengan tiga kali ulangan. Salinitas medium NB diatur sebesar 3, 5, 7 dan 9. Suspensi kemudian diinkubasikan dalam suhu kamar selama kurang lebih 24 jam. Satu tabung medium NB steril tanpa inokulasi bakteri juga diinkubasikan ke dalam inkubator dengan berbagai variasi $\mathrm{pH}$ tersebut sebagai kontrol perlakuan. Hasil pengamatan 
kualitatif pertumbuhan dalam variasi $\mathrm{pH}$ kemudian diamati dengan kontrol sebagai pembanding.

Kebutuhan Oksigen

Satu ose isolat Rhizobakteri dari medium NA miring kemudian diinokulasikan dengan ose bulat ke dalam medium NB steril. Satu seri medium NB steril yang telah diinokulasikan oleh biakan bakteri ditumbuhkan dalam kondisi aerob untuk mengetahui pengaruh oksigen bebas terhadap pertumbuhan bakteri secara kualitatif. Seri suspensi medium NB steril dengan biakan bakteri ditumbuhkan dalam kondisi anaerob dalam anaerobic jar. Suspensi kemudian diinkubasikan dalam suhu kamar selama kurang lebih 24 jam. Satu tabung medium NB steril tanpa inokulasi bakteri juga diinkubasikan sebagai kontrol perlakuan. Hasil pengamatan kualitatif pertumbuhan dalam kondisi aerob dan anaerob kemudian diamati dengan kontrol sebagai pembanding. Isolat potensial kemudian dikelompokkam ke dalam organisme anaerob, aerob dan fakultatif anaerob sesuai dengan hasil pengamatan pertumbuhan kualitatif dalam kedua kondisi oksigen tersebut.

\section{Hasil dan Pembahasan}

\subsection{Isolasi dan penampisan Rhizobakteri pelarut fosfat potensial}

Isolasi rhizobakteri pelarut fosfat dari tiga sampel tanah rhizosfer tumbuhan mangrove Sonneratia sp., Rhizophora sp. dan Calotropis gigantea mendapatkan 8 isolat dengan karakter morfologi koloni yang tertera pada Tabel 1 .

Penelitian isolasi rhizobakteri pelarut fosfat menunjukkan keberadaan rhizobakteri pada semua sampel tanah rhizosfer yang diteliti. Bharathkumar et al. (2008) menjelaskan bahwa keberadaan rhizobakteri pelarut fosfat pada sampel tanah rhizosfer mangrove yang diteliti menunjukkan adanya siklus nutrisi dalam ekosistem ini. Daerah eksudat akar secara umum merupakan daerah yang menyediakan berbagai sumber nutrisi untuk kehidupan mikroorganisme di ekosistem lahan mangrove (Sudha Nair et al., 2008). Nutrisi-nutrisi berupa senyawa metabolit yang dilepaskan oleh tanaman melalui akar berupa senyawa gula, asam amino, asam organik, glikosida, senyawa nukleotida, vitamin, enzim, dan senyawa indol (Rodriguez \& Fraga, 1999).

Sementara itu, Kothamasi et al. (2006) melaporkan bahwa perakaran Rhizophora sp. dan Sonneratia sp. memiliki akar nafas (pneumatofora) yang mampu mendukung pergerakan oksigen ke daerah akar yang terendam. Cooke et al. (1993) dan Brown \& Bledsoe (1996) dalam Kothamasi et al. (2006) menuliskan bahwa akar yang terendam tersebut, seperti tanaman-tanaman akuatik lainnya, memiliki korteks aerenkim, dengan jaringan-jaringan yang dilaporkan mampu menyediakan oksigen untuk akar dan mendukung kolonisasi dan ketahanan hidup Arbuscular Mycorrhizae Fungus (AMF) pada tanaman yang tumbuh pada habitat yang tergenang air.

Kedelapan isolat yang didapat menunjukkan penampakan koloni yang berbeda-beda, ditinjau dari bentuk, warna, dan elevasi koloni. Sejalan dengan penelitian ini, penelitian Nisa' (2018) mendapatkan 3 (tiga) isolat bakteri pelarut fosfat dengan karakter koloni; bentuk yang ketiganya bulat; elevasi datar, datar, dan rata; dan warna putih susu, putih, dan kuning. Karakter-karakter koloni ini digunakan sebagai pembeda awal isolat yang diperoleh, untuk proses karakterisasi selanjutnya.

Tabel 1. Morfologi Koloni Rhizobakteri Pelarut Fosfat dari Tiga Sampel Tanah Rhizosfer Tumbuhan Mangrove yang Berbeda (berdasarkan Cappucino \& Shermann, 1987)

\begin{tabular}{|c|c|c|c|c|}
\hline Isolat & Asal Rhizosfer & Bentuk koloni & Warna & Elevasi \\
\hline EO-1 & Sonneratia sp. & Tak beraturan & Krem & Datar \\
\hline EO-2 & Sonneratia sp. & Bulat & Transparan & Umbonate \\
\hline EO-3 & Rhizophora sp. & Tak beraturan & Transparan & Umbonate \\
\hline EO-4 & Rhizophora sp. & Oval & Krem & Datar \\
\hline EO-5 & Rhizophora sp. & Bulat & Putih susu & Umbonate \\
\hline EO-6 & C.gigantea & Bulat & Kuning & Umbonate \\
\hline EO-7 & C.gigantea & Bulat & Hijau & Umbonate \\
\hline EO-8 & C.gigantea & Tak beraturan & Putih susu & Umbonate \\
\hline
\end{tabular}

Sumber nutrisi dan berbagai faktor fisik serta kimia yang terdapat dalam sampel tanah yang diteliti dapat mempengaruhi keberadaan rhizobakteri pelarut fosfat dalam tanah. Karakter sampel tanah rhizosfer yang dteliti dapat dilakukan dengan pengamatan warna fisik tanah. Collins (2003) dan Krull et al. (2005) menjelaskan bahwa warna tanah merupakan parameter yang paling mudah digunakan untuk menentukan sifat-sifat tanah yang diteliti. Warna tanah dapat dihubungkan dengan beberapa sifat fisik, kimia dan biologi tanah. Analisis kuantitatif kandungan kimia tanah unsur fosfor (P) juga telah dilakukan untuk mengetahui jumlah P yang terdapat dalam sampel tanah sebagai bahan yang dapat dilarutkan oleh rhizobakteri pelarut fosfat, sehingga dapat diserap oleh tumbuhan, khususnya tumbuhan mangrove. Hasil analisis kandungan rata-rata total $P$ dalam sampel tanah yang diteliti menunjukkan bahwa tanah yang berwarna coklat kehitaman memiliki kandungan $\mathrm{P}$ tertinggi jika dibandingkan dengan dua jenis sampel tanah lain yang memiliki warna merah. Karakter warna tanah dan kandungan $\mathrm{P}$ dalam masing-masing sampel tanah rhizosfer yang diteliti dapat dilihat pada Tabel 2. 
Kandungan P $(529,164 \mathrm{mg} / \mathrm{kg})$ tertinggi dalam sampel tanah rhizosfer mangrove tumbuhan Rhizophora sp. yang berwarna coklat kehitaman sedangkan tanah yang berwarna coklat kemerahan memiliki kandungan $\mathrm{P}$ terendah $(168,422 \mathrm{mg} / \mathrm{kg})$. Channarayappa \& Biradar (2019) menuliskan bahwa warna tanah memberikan informasi tentang kandungan bahan organik, tingkat drainase, aktivitas biotik, dan kesuburan tanah. Lebih lanjut Channarayappa \& Biradar (2019) menuliskan bahwa adanya substrat organik pada tanah dicirikan dengan warna tanah yang lebih gelap, adanya oksida besi pada tanah dapat memberikan warna lapisan coklat dan kemerahan, adanya senyawa karbonat dapat menimbulkan warna keputih-putihan sebagian, dan adanya kondisi reaksi oksidasi (oksida besi yang tereduksi) dapat memberikan warna abu-abu dan kehijau-hijauan sebagian. Sehingga, lebih lanjut dituliskan oleh Channarayappa \& Biradar (2019), bahwa perkembangan dan distribusi warna pada profil tanah dihasilkan dari proses biologis dan kimiawi, khususnya reaksi oksidasi-reduksi.

Tabel 2. Karakter Warna Tanah dan Total Kandungan Fosfor dalam Tiga Sampel Tanah Rhizosfer yang Diteliti

\begin{tabular}{cccc}
\hline \hline Kode Sampel Tanah & Rhizosfer Tumbuhan Mangrove & Warna Tanah & Kandungan P (mg/kg) \\
$\mathbf{1}$ & Sonneratia sp. & Merah kecoklatan & 233,527 \\
$\mathbf{2}$ & Rhizophora sp. & Coklat kehitaman & 529,164 \\
$\mathbf{3}$ & C.gigantea & Coklat kemerahan & 168,422 \\
\hline \hline
\end{tabular}

Keterangan :

Kandungan P menunjukkan jumlah total unsur P dalam senyawa fosfat, baik yang terdapat dalam senyawa yang tersedia maupun yang tidak tersedia untuk tumbuhan

Kandungan total unsur $\mathrm{P}$ dalam tanah merupakan salah satu faktor yang mempengaruhi jumlah $\mathrm{P}$ dalam tanah yang dapat diserap oleh tumbuhan, disamping faktor lain seperti jenis tanah, pH tanah, suhu, pertukaran udara, kelembapan udara dan kandungan nutrisi lain dalam tanah (Hodges, tanpa tahun). Keberadaan rhizobakteri pelarut fosfat dalam sampel tanah juga dapat mempengaruhi jumlah P yang dapat diserap oleh tumbuhan karena kemampuan rhizobakteri dalam melakukan pelarutan fosfat. Faktor-faktor fisik dan kimia tanah seperti $\mathrm{pH}$ tanah, suhu, pertukaran udara, kelembapan udara dan kandungan nutrisi juga merupakan faktor yang menentukan keberadaan rhizobakteri pelarut fosfat karena jenis rhizobakteri ini juga membutuhkan kondisi tertentu dalam mendukung mekanisme pelarutan fosfat dalam tanah.

Di India, sebagai negara dengan iklim yang sama dengan Indonesia, yakni iklim tropis, rata-rata kandungan total $\mathrm{P}$ pada tanah yang berwarna hitam pada kedalaman sekitar 0-30 cm di zona yang berbeda, bervariasi dari $275 \mathrm{mg} / \mathrm{kg}$ (di daerah basah) hingga $459 \mathrm{mg} / \mathrm{kg}$ (di daerah semi kering). Tanah yang berwarna merah di India memiliki rata-rata kandungan total P (pada kedalaman antara 0-30 cm) yang bervariasi dari $184 \mathrm{mg} / \mathrm{kg}$ (di daerah semi kering) hingga $854 \mathrm{mg} / \mathrm{kg}$ (di daerah basah). Kandungan $P$ dalam sampel tanah yang diteliti berada dalam jangkauan antara 168, 422 mg/kg hingga 529, $164 \mathrm{mg} / \mathrm{kg}$. Nilai kandungan P dalam bentuk senyawa fosfat ini berada dalam jangkauan kandungan $\mathrm{P}$ sampel tanah di India pada beberapa jenis warna tanah yang diteliti oleh Ramesh et al. (2007). Pritchard (2005) juga melaporkan bahwa kandungan total P (kedalaman antara $0-10 \mathrm{~cm}$ ) dari tanah yang terdapat di lembah Bakers, di sebelah barat daya Australia adalah sebesar $69 \mathrm{mg} / \mathrm{kg}$ dan dikategorikan dalam status unsur P yang rendah dalam tanah.

Kedelapan isolat rhizobakteri pelarut fosfat dilakukan penapisan dengan mengacu pada penelitan Girish et al. (2010). Hasil penapisan kemampuan pelarutan fosfat dapat dilihat pada Gambar 1 . Penggunaan angka indeks pelarutan fosfat untuk mengetahui kemampuan pelarutan fosfat secara invitro telah digunakan oleh beberapa peneliti (Ahemad \& Khan, 2010; Calvo et al., 2010; Girish et al., 2010; Carmo et al., 2011). Besar indeks pelarutan fosfat menunjukkan efisiensi relatif dari isolat mikroorganisme yang diteliti terhadap kemampuan

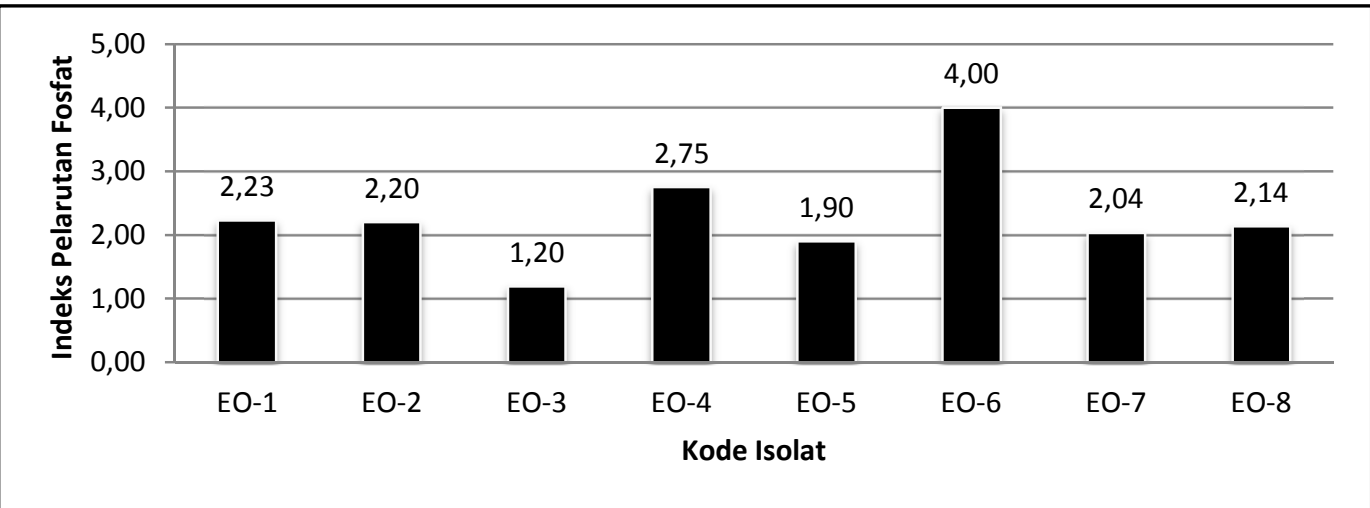

Gambar 1 Indeks Pelarutan Fosfat Isolat Rhizobakteri Pelarut Fosfat dalam Medium Pikovskaya Agar selama 7 Hari 
menghasilkan zona bening pada medium uji karena adanya produksi asam organik dan enzim fosfatase yang dikeluarkan di sekeliling koloni mikroorganisme tertentu (Mehta \& Nautiyal, 2001; Ginting $d k k ., 2005$; Jha et al., 2009). Zona bening menunjukkan aktivitas rhizobakteri dalam melarutkan fosfat dalam medium uji, yaitu jenis trikalsium fosfat $\left(\mathrm{Ca}_{3}\left(\mathrm{PO}_{4}\right)_{2}\right)$. Isolat yang menunjukkan indeks pelarutan fosfat tertinggi digunakan untuk identifikasi selanjutnya, yaitu isolat dengan kode EO-6 dan indeks pelarutan fosfat sebesar 4,00. Isolat E0-6 merupakan isolat yang berhasil diperoleh dari tanah rhizosfer tumbuhan $C$. gigantea.

\subsection{Karakterisasi Rhizobakteri Pelarut Fosfat Potensial}

Isolat E0-6 merupakan isolat yang memiliki indeks pelarutan fosfat tertinggi, namun hanya bisa ditumbuhkan pada subkultur ketiga hingga keempat. Hal ini dapat disebabkan karena sebagian besar organisme Prokariota sampai saat ini sulit untuk dapat dikulturkan pada medium buatan karena keterbatasan untuk dapat menyamai kondisi sesungguhnya di alam (Suwanto, 1994; Pangastuti, 2006). Sebesar kurang lebih hanya $1 \%$ dari seluruh Prokariota yang terdapat di alam, yang dapat dikulturkan di laboratorium (Kirk et al., 2004). Isolat EO-4 yang memiliki indeks pelarutan fosfat sebesar 2,75 digunakan untuk tahap karakterisasi selanjutnya. Karakterisasi mikrobiologi dilakukan dengan mengamati morfologi, aktivitas biokimia dan kemampuan pertumbuhan dalam beberapa faktor lingkungan, yang dapat dilihat pada Tabel 3.

Karakter isolat potensial dengan kode EO-4 ini merupakan bakteri gram negatif. Cappuccino \& Sherman (2014) menuliskan bahwa pewarnaan gram merupakan jenis pewarnaan diferensiasi, yang dapat digunakan sebagai metode penting dalam mengelompokkan dan membedakan mikroorganisme. Lebih lanjut Cappuccino \& Sherman (2014) menuliskan bahwa reaksi pewarnaan gram ini berdasarkan pada perbedaan komposisi kimia dinding sel bakteri. Dinding sel bakteri gram negatif memiliki peptidoglikan yang lebih tipis dan dilapisi dengan lapisan terluar (outer membrane) yang terdiri dari senyawa lipid (Fardiaz, 1989; Cappuccino \& Sherman, 2014). Peptidoglikan adalah polisakarida yang terdiri dari dua subunit kimia yang hanya ditemukan pada dinding sel bakteri, yakni $N$ acetylglucosamine dan $N$-acetylmuramic acid (Cappuccino \& Sherman, 2014).

Isolat yang diteliti bereaksi negatif terhadap reaksi hidrolisis pati dalam medium padat. Menurut Cappuccino \& Sherman (2014), pati merupakan molekul dengan berat molekul besar (makromolekul), yang merupakan polimer bercabang dan terdiri dari molekul glukosa yang dihubungkan dengan ikatan bi63 glikosidik. Lebih lanjut Cappuccino \& Sherman (2014) menuliskan bahwa degradasi awal makromolekul ini membutuhkan kehadiran enzim ekstraseluler, yakni amilase, untuk reaksi hidrolisis menjadi polisakarida yang lebih pendek, yang disebut sebagai dekstrin, dan selanjutnya menjadi molekul maltosa. Selanjutnya, disakarida maltosa ini akan dihidrolisis lagi sehingga didapatkan molekul gula sederhana berupa glukosa, yang ditranspor ke dalam sel dan masuk ke dalam reaksi glikolisis untuk konversi menjadi ATP (Cappuccino \& Sherman, 2014).

Isolat ini bereaksi positif terhadap pengujian hidrolisis sitrat. Menurut Cappuccino \& Sherman (2014), pada ketidakhadiran glukosa atau laktosa yang terfermentasi, beberapa mikroorganisme mampu menggunakan sitrat sebagai sumber karbon untuk memenuhi kebutuhan energi. Adanya enzim citrate permease yang membantu transpor sitrat ke dalam sel menjadi kunci berlangsungnya reaksi tersebut (Cappuccino \& Sherman, 2014). Berg et al. (2002) menuliskan bahwa dalam siklus ini, akan dihasilkan beberapa produk, yakni 2 (dua) molekul $\mathrm{CO}_{2}$, satu molekul GTP, dan elektron berenergi tinggi dalam bentuk NADH dan $\mathrm{FADH}_{2}$. Selama reaksi ini, medium menjadi basa, karena $\mathrm{CO}_{2}$ yang dihasilkan bereaksi dengan $\mathrm{Na}$ dan air untuk membentuk natrium karbonat, produk yang bersifat basa (Cappuccino \& Sherman, 2014). Lebih lanjut Cappuccino \& Shermann (2014) menuliskan bahwa keberadaan natrium karbonat mengubah indikator Brom Thymol Biru dalam medium dari warna hijau menjadi warna biru Persia gelap.

Selanjutnya, isolat ini bereaksi negatif terhadap reaksi yang menentukan ada atau tidaknya kemampuan untuk menghasilkan senyawa indol. Cappuccino \& Sherman (2014) menuliskan bahwa asam amino esensial triptofan di dalam medium, dengan bantuan katalisis enzim tryptophanase di dalam sel bakteri, akan mampu menghasilkan indol, yang dideteksi dengan adanya lapisan reagen berwarna merah cherry setelah penambahan reagen Kovac's. Akan tetapi, isolat ini tidak menghasilkan indol, karena tidak terjadinya reaksi hidrolisis triptofan dalam medium.

Dalam uji aktivitas enzim katalase, isolat ini bereaksi positif. Menurut Cappuccino \& Sherman (2014), selama respirasi aerobik, mikroorganisme menghasilkan hidrogen peroksida dan dalam beberapa kasus, superoksida lain yang toksik bagi sel. Menurut Zhao \& Drlica (2014), selain hidrogen peroksida dan superoksida, senyawa lain yang juga dikelompokkan ke dalam jenis senyawa Reactive Oxygen Species (ROS) ini adalah hidroksi radikal bebas. Lebih lanjut Cappuccino \& Sherman (2014) menuliskan bahwa substansi kimia tersebut dihasilkan ketika mikroorganisme aerobik, fakultatif anaerob, dan mikroaerofil menggunakan jalur respirasi aerobik, di mana oksigen merupakan 
Tabel 3. Karakter Mikrobiologi Isolat EO-4 Dibandingkan dengan Enterobacter (berdasarkan Bergey's Manual of Determinative Bacteriology)

\begin{tabular}{|c|c|c|c|}
\hline No. & Karakter & Hasil Uji & Enterobacter (dari referensi) \\
\hline \multirow[t]{6}{*}{1.} & Morfologi Koloni & & \\
\hline & - Bentuk & Oval & TD \\
\hline & - $\quad$ Tepian & Entire & Entire \\
\hline & - $\quad$ Elevasi & Datar & TD \\
\hline & - Warna & Krem & TD \\
\hline & - $\quad$ Pertumbuhan medium cair & Sedimen & Sedimen \\
\hline \multirow[t]{2}{*}{2.} & Morfologi Sel & & \\
\hline & - Gram, bentuk & - (negatif), batang pendek & - (negatif), batang pendek \\
\hline \multirow[t]{9}{*}{3.} & Aktivitas Biokimia & & \\
\hline & - $\quad$ Hidrolisis pati & - & - \\
\hline & - $\quad$ Penggunaan sitrat & + & + \\
\hline & - $\quad$ Produksi indol & - & - \\
\hline & - $\quad$ Enzim katalase & + & - \\
\hline & - $\quad$ Fermentasi karbohidrat & & \\
\hline & a. Sukrosa & $+(\mathrm{AG})$ & + \\
\hline & b. Dekstrosa & $+(\mathrm{AG})$ & + \\
\hline & c. Laktosa & $+(\mathrm{AG})$ & + \\
\hline \multirow[t]{4}{*}{4.} & Variasi Suhu Pertumbuhan & & \\
\hline & a. $25^{\circ} \mathrm{C}$ & + & + \\
\hline & $37^{\circ} \mathrm{C}$ & + & + \\
\hline & c. $\quad 47^{\circ} \mathrm{C}$ & + & TD \\
\hline \multirow[t]{5}{*}{5.} & Variasi pH Pertumbuhan & & \\
\hline & a. 3 & - & - \\
\hline & b. & + & + \\
\hline & c. & + & + \\
\hline & d. 9 & + & + \\
\hline \multirow[t]{5}{*}{6.} & Variasi Salinitas Pertumbuhan & & \\
\hline & a. $\quad 0,85 \%$ & + & + \\
\hline & $5 \%$ & + & - \\
\hline & $10 \%$ & - & - \\
\hline & d. $\quad 15 \%$ & - & - \\
\hline \multirow[t]{3}{*}{7.} & Ketersediaan Oksigen Bebas & & \\
\hline & a. Dengan $\mathrm{O}_{2}$ & + & + \\
\hline & b. Tanpa $\mathrm{O}_{2}$ & + & + \\
\hline
\end{tabular}

Keterangan :

a. Tanda + menunjukkan hasil uji yang positif

b. Tanda - menunjukkan hasil uji yang negatif

c. Tanda AG menunjukkan produksi asam dan gas

Tanda TD menunjukkan bahwa uji tersebut tidak dibedakan

penerima elektron terakhir, ketika terjadi reaksi degradasi karbohidrat untuk menghasilkan energi. Organisme yang menghasilkan enzim katalase mampu secara cepat mendegradasi hidrogen peroksida $\left(\mathrm{H}_{2} \mathrm{O}_{2}\right)$ menjadi air $\left(\mathrm{H}_{2} \mathrm{O}\right)$ dan oksigen $\left(\mathrm{O}_{2}\right)$ (Cappuccino \& Sherman, 2014).

Dalam uji fermentasi karbohidrat, yang menggunakan sumber karbohidrat sukrosa, dekstrosa, dan laktosa, isolat yang diteliti mampu menggunakan sumber karbon tersebut sebagai substrat fermentasi, dan dihasilkan produk berupa asam dan gas, pada semua uji yang dilakukan. Menurut Cappuccino \& Sherman (2014), dalam proses fermentasi, substrat seperti karbohidrat dan alkohol akan mengalami dissimilasi anaerob dan menghasilkan asam organik (seperti asam laktat, asam format, dan asam asetat), yang dapat diikuti dengan pembentukan gas seperti hidrogen atau karbondioksida. Proses fermentasi paling mudah dideskripsikan dengan degradasi glukosa melalui jalur Embden-Meyerhof, yang juga disebut dengan jalur glikolitik (Cappuccino \& Sherman, 2014).

Pengaruh faktor lingkungan yang diteliti pada isolat potensial ini, salah satunya berupa suhu. Suhu 64 dan pH merupakan dua aspek yang mempengaruhi kinerja enzim dalam sel (Robinson, 2015). Lebih lanjut Robinson (2015) menuliskan bahwa pengaruh suhu terhadap aktivitas enzim sangat kompleks, dan dapat dipandang sebagai dua aspek yang bertindak secara simultan, namun berada dalam arah yang berbeda. Capuccino \& Sherman (2014) menuliskan bahwa suhu yang rendah dapat memperlambat atau menghambat aktivitas enzim, sehingga menghambat metabolisme sel, dan berdampak pada penghambatan pertumbuhan sel, sedangkan suhu yang tinggi dapat mengakibatkan proses denaturasi enzim-enzim yang termolabil. Lebih lanjut Cappuccino \& Sherman (2014) menuliskan bahwa mikroorganisme mampu tumbuh pada jangkauan suhu yang lebar, akan tetapi, suhu optimum yang umum digunakan untuk kultur sebagian besar mikroba adalah pada $37^{\circ} \mathrm{C}$ selama periode 18 hingga 24 jam.

Selanjutnya, isolat yang diteliti tidak mampu tumbuh pada $\mathrm{pH}$ 3. Derajat keasaman juga sama seperti suhu, mampu mempengaruhi aktivitas enzim (Cappuccino \& Sherman, 2014). Lebih lanjut Cappuccino \& Sherman (2014) juga menuliskan bahwa umumnya, pH optimum untuk reaksi 
metabolisme adalah pH netral 7, sehingga, penurunan dan peningkatan $\mathrm{pH}$ (pada kondisi asam dan basa) akan menurunkan laju reaksi kimia karena adanya kerusakan enzim seluler, dan lebih jauh lagi, mempengaruhi tingkat pertumbuhan dan daya tahan sel.

Pengujian variasi konsentrasi kadar garam terhadap kultur sel menunjukkan bahwa isolat yang diteliti tidak mampu tumbuh pada konsentrasi kadar garam $10 \%$ dan 15\%. Kadar garam yang tinggi dalam medium dapat memberikan tekanan osmotik bagi sel karena kondisi hipertonik di luar sel (Cappuccino \& Sherman, 2014). Garam, khususnya dalam bentuk $\mathrm{NaCl}$, dapat menginduksi adanya kontraksi pada dinding sel bakteri gram negatif, dan hal ini berkaitan erat dengan pembengkakan sel dan plasmolisis yang dapat diamati secara keseluruhan pada sel (Marquis, 1968).

Faktor lingkungan lain yang diteliti adalah pengaruh ada dan tidaknya oksigen terhadap pertumbuhan sel isolat bakteri yang diteliti. Isolat bereaksi positif terhadap kondisi ada dan tidak adanya oksigen. Menurut Cappuccino \& Sherman (2014), oksigen atmosferik berperan penting dalam pembentukan ATP dan ketersediaan energi dalam bentuk yang dapat digunakan untuk aktivitas sel, dengan menggunakan mekanisme reaksi respirasi aerobik. Akan tetapi, ketika berada dalam kondisi tidak ada oksigen (anaerob), sel menggunakan jalur lain untuk menghasilkan energi, yakni mekanisme respirasi anaerobik atau fermentasi (alkohol dan asam laktat) (Cappuccino \& Sherman, 2014).

Karakter rhizobakteri pelarut fosfat berdasarkan beberapa uji yang telah dilakukan menunjukkan bahwa isolat EO-4 yang diperoleh memiliki karakter yang mirip dengan genus Enterobacter (berdasarkan Bergey's Manual of Determinative Bacteriology). Genus Enterobacter (khususnya Enterobacter aerogenes, E.tay/orae dan E.asburiae) merupakan jenis rhizobakteri pelarut fosfat yang berhasil diisolasi oleh Sahoo \& Dahl (2009) dari ekosistem mangrove di Meksiko, selain Bacillus amyloliquefaciens, B.atrophaeus, Paenibacillus macerans, Xanthobacter agilis, Vibrio proteolyticus, Kluyvera cryocrescens, B.licheniformis, Chryseomonas luteola dan Pseudomonas stutzeri.

\section{Kesimpulan}

Isolat rhizobakteri pelarut fosfat potensial yang diisolasi dari tanah rhizosfer tumbuhan Rhizophora sp. di ekosistem mangrove Teluk Awur Kabupaten Jepara, dengan kode EO-4, menghasilkan indeks pelarutan fosfat sebesar 2,75. Karakter yang diteliti berupa morfologi koloni, morfologi sel, aktivitas biokimia, dan pengaruh faktor lingkungan terhadap pertumbuhan sel (suhu, pH, kadar garam, dan ketersediaan oksigen). Koloni sel isolat tersebut memiliki bentuk oval, tepian entire, elevasi datar, dan warna krem. Sel bakteri ini merupakan bakteri gram negatif, dengan bentuk sel berupa batang pendek (rod). Isolat ini mampu menggunakan sitrat dalam medium uji dan menghasilkan enzim katalase, akan tetapi, tidak mampu menghidrolisis pati dalam medium dan tidak menghasilkan indol sebagai hasil reaksi hidrolisis asam amino triptofan dalam medium. Isolat ini juga mampu melakukan fermentasi karbohidrat berupa sukrosa, dekstosa, dan laktosa dalam medium, dan menghasilkan asam dan gas. Dilihat dari aspek faktor pertumbuhan yang diteliti, isolat ini mampu tumbuh pada suhu hingga $47^{\circ} \mathrm{C}$, mampu tumbuh dengan ada maupun tidak adanya oksigen bebas, tidak mampu tumbuh pada $\mathrm{pH} \mathrm{3,} \mathrm{dan}$ tidak mampu tumbuh pada kadar garam $10 \%$ dan 15\%. Berdasarkan karakter-karakter tersebut, secara mikrobiologi dan atau aktivitas biokimia, isolat potensial pelarut fosfat ini diidentifikasikan ke dalam genus Enterobacter.

\section{DAFTAR PUSTAKA}

Ahemad, M \& Khan, M.S., (2010), Plant Growth Promoting Activities of Phosphate Solubilizing Enterobacter asburiae as Influenced by Fungicides, Eur. Asian Journal of Biosciences, 4, 88-95.

Banerjee, S., Palit, R., Sengupta, C \& Standing, D., (2010), Stress Induced Phosphate Solubilization by Arthrobacter sp. and Bacillus sp. Isolated from Tomato Rhizosphere, Australian Journal of Crop Science, 4(6), 378-383.

Bariusso, J., Solano, B.R., Lucas, J.A., Lobo, A.P., GarciaVillaraco, A \& Manero, F.J.G., (2008), Plant-Bacteria Interactions, Strategies and Techniques to Promote Plant Growth : Ecology, Genetic Diversity and Screening Strategies of Plant Growth Promoting Rhizobacteria $(P G P R)$, Wiley-VCH Verlag GmbH \& Co. KgaA, Weinhem.

Berg, J.M., Tymoczko, J.L., Stryer, L, (2002), Biochemistry 5th Edition, W H Freeman and Company, New York.

Bharatkumar, S., Rameshkumar, N., Paul, D., Prabavaty, V.R \& Sudha Nair., (2008), Characterization of the Predominant Bacterial Population of Different Mangrove Rhizosphere Soil Using 16S rRNA GeneBased Single-Strand Conformation Polymorphism (SSCP), World J Microbiol Biotechnol, 24, 387-394.

Calvo, P., Ormeño-Orrillo, E., Martínez-Romero, E. \& Zúñiga, D., (2010), Characterizarion of Bacillus Isolates of Potato Rhizosphere from Andean Soils of Peru and Their Potential PGPR Characteristics, Brazilian Journal of Microbiology, 41, 899-906.

Cappucino, J.G. \& Sherman, N., (1987), Microbiology: A Laboratory Manual, The Benjamin/Cummings Publishing Company Inc., California USA.

Cappucino, J.G. \& Sherman, N., (2014), Microbiology: A Laboratory Manual, Pearson Education, United States of America.

Carmo, F.L., Santos, H.F., Martins, E.F., Elsas, J.D., Rosado, A.S. \& Peixoto, R.S., (2011), Bacterial Structure and Characterization of Plant Growth and Oil Degrading Bacteria from the Rhizosphere of Mangrove Plants, The Journal of Microbiology, 49(4), 535-543. 
Channarayappa, Biradar, D.P., (2019), Soil Basics, Management, and Rhizosphere Engineering for Sustainable Agriculture. CRC Press, Florida, USA.

Collins, M.E., (2003), Soil Section : Key to Soil Orders in Florida. Florida Envirothon Study Sections University of Florida, Florida, United States America.

Dastager, S.G., Deepa, C.K., Puneet, S.C., Nautiyal, C.S \& Pandey, A., (2009), Isolation and Characterization of Plant Growth-Promoting Strain Pantoea NII-186. from Western Ghat Forest Soil, India, Journal Compilation 2009 The Society for Applied Microbiology, Letters in Applied Microbiology, 49, 20-25.

Dewi, I.R., (2007), Makalah : Rhizobacteria Pendukung Pertumbuhan Tanaman Plant Growth Promotor Rhizobacteria, Universitas Padjdjaran, Jatinangor

Fachrul, M.F., (2007), Metode Sampling Bioekologi, Bumi Aksara, Jakarta

Fardiaz, S., (1989), Mikrobiologi Pangan, Institut Pertanian Bogor, Bogor, Indonesia.

Ginting, R.C.B., Saraswati, R \& Husen, E., (2005), 7. Mikroorganisme Pelarut Fosfat : Pupuk Organik \& Pupuk Hayati, dalam Pupuk Hayati dan Pupuk Organik, ed Suriadikarta \& Simanungkalit, hal. 141-158.

Girish, K., Shrikant, B., Sunil, M \& Manish, D., (2010), Exploring the Potential of Pseudomonas Species as a Phosphate Solubilizer, Plant Growth Promoter, Biocontrol Agent and Pesticide Degrader. Asian J. Exp. Biol. Sci., 40-44.

Hariyono, (2007), Status Lingkungan Hidup Daerah Kabupaten Jepara, Dinas Lingkungan Hidup Pertambangan dan Energi. Jepara.

Hodges, S.C., (tanpa tahun), Soil Science Extension North Carolina University : Soil Fertility Basics, NC Certified Crop Advisor Training, North Carolina University, North Carolina.

Jha, B.K., Pragash, M.G., Cletus, J., Raman, G \& Sakthivel, N., (2008), Simultaneous Phosphate Solubilization Potential and Antifungal Activity of New Fluorescent Pseudomonad Strains, Pseudomonas aeruginosa, $P$. plecoglossicida and P. Mosselii, World J Microbiol Biotechnol, 25, 573-581.

Kirk, J.L., Beaudette, L.A., Hart, M., Moutoglis, P, Klironomos, J.N., Lee, H \& Trevors, J.T., (2004), Review : Methods of Studying Soil Microbial Diversity, Journal of Microbiological Methods, 58, 169- 188.

Kothamasi, D., Kothamasi, S., Bhattacharyya, A., Kuhad, R.C. \& Babu, C.R., (2006), Arbuscular Mycorrhizae and Phosphate Solubilising Bacteria of the Rhizosphere of the Mangrove Ecosystem of Great Nicobar Island, India, Biol Fertil Soils, 42, 358-361.

Krull, E.S., Skjemstad, J.0 \& Baldock, J.A., (2005), GRDC Project No. CSO 00029 Residue Management, Soil Organic Carbon and Crop Performance: Functions of Soil Organic Matter and the Effect on Soil Properties, CSIRO Land \& Water PMB 2 Glen Osmond S.A 5064.

Lee, K.D., Bai, Y., Smith, D., Han, H.S \& Supanjani., (2005), Isolation of Plant-Growth-Promoting Endophytic Bacteria from Bean Nodules, Research Journal of Agriculture and Biological Sciences, 1(3), 232-236.

Marquis, R.E., (1968), Salt-Induced Contraction of Bacterial Cell Walls, Journal of Bacteriology, 95 (3), 775-781.
Mehta, S \& Nautiyal, C.S., (2001), An Efficient Method for Qualitative Screening of Phosphate-Solubilizing Bacteria, Current Microbiology, 43, 51-56.

Mishra, R.R.,Dangar, T.K., Rath, B \& Thatoi H, N., (2009), Characterization and Evaluation of Stress and Heavy Metal Tolerence of Some Predominant Gram Negative Halotolerant Bacteria From Mangrove Gills of Bhitarkanika, Orissa, India, African Journal of Biotechnology, 8(10), 2224-2231.

Nisa', N.A., (2018), Isolasi dan Identifikasi Bakteri Pelarut Fosfat dengan Sekuens 16S rRNA Asal Tanah Pertanian Organik Desa Sumberejo Batu. Skripsi. Universitas Islam Negeri Maulana Malik Ibrahim, Malang.

Pangastuti, A., (2006), Review: Definisi Spesies Prokariota Berdasarkan Urutan Basa Gen Penyandi 16S rRNA dan Gen Penyandi Protein, Biodiversitas, 7 (3), 292- 296.

Pritchard, D.L., (2005), Muresk Institute : Phosphorus Bioavailability from Land-Applied Biosolids in SouthWestern Australia, Thesis, Curth University of Technology, Australia.

Ramesh, V., Wani, S.P., Rego, T.J., Sharma, K.L., Bhattacharyya, T., Sahrawat, K.L., Padmaja, K.V., Gangadhar Rao, D., Venkateswarlu, B., Vanaja, M., Manna, M.C., Sanvas, K \& Maruthi, V., (2007), Chemical Characterization of Selected Benchmark Spots for C Sequestration in the Semi-Arid Tropics, India. International Crops Research Institute for the SemiArid Tropics. India.

Robinson, P.K., 2015. Enzymes: Principles and Biotechnological Applications. Essays Biochem, 59, 141.

Rodríguez, H., \& Fraga, R., (1999), Phosphate Solubilizing Bacteria and Their Role in Plant Growth Promotion. Biotechnology Advances of Cuban Research Institute, 17, 319-339.

Sahoo, K \& Dahl, N.K., (2009), Potential Microbial Diversity in Mangrove Ecosystems: A Review, Indian Journal of Marine Sciences, 38(2), 249-256.

Sudha Nair, Sasirekha, N., Appunu, C., Bharathkumar, S., Loganathan, P., Rameshkumar, N., Sridhar, R., Subathra, G \& Prabhavathy, V.R., (2008), Microbial Diversity in Mangrove Ecosystem. M.S. Swaminathan Research Foundation 3rd Cross Road, Taramani Institutional Area, Chennai-600113. National Institute of Agricultural Sciences and Technology, Suwon, South Korea \& Medical Entomology, Dept. of Entomology, N. C. State University, Raleigh.

Suwanto, A., (1994), Ulas Balik: Evolusi Mikrobe dan Kaitannya dengan Sistematik Molekuler, Hayati, 1 (2), 26-31.

Thuller, D.S., Floh, E.I.S., Handro, W \& Barbosa, H.R., (2003), Plant Growth Regulator and Amino Acids Released by Azospirillum sp. in Chemically Defined Media, Letters in Applied Microbiology, 37, 174-178.

Waluyo, L., (2008), Teknik Metode Dasar Mikrobiologi. Universitas Muhamadiyah Malang Press, Malang.

Zhao, X. \& Drlica, K., (2014), Reactive Oxygen Species and The Bacterial Response to Lethal Stress, Curr Opin Microbiol, 21, 1-6. 